\title{
Effects of Conflict Resolution approaches on Household Economy in Wajir East Sub-County Wajir County, Kenya

\author{
Omar, D. Khalid
}

Mount Kenya University, Thika, Kenya

DOI: $10.29322 /$ IJSRP.10.08.2020.p104108

http://dx.doi.org/10.29322/IJSRP.10.08.2020.p104108

\begin{abstract}
Conflict is the occurrence of competition, aggressive mentality, antagonism and hostility among different communities with varying opinion and interests. Several strategies from traditional to modernized/civilized have been utilized over time without success in Wajir East Sub-County of the larger Wajir County in Kenya. The current work, therefore aimed at establishing effects of conflict resolution approaches on household economic development in the perspective of Wajir East Sub-County. Specifically, the academic work sought to find out the influence of mediation, arbitration and negotiation by council of elders on household economic development.

Descriptive research design utilizing stratified random sampling technique to sample and subject semi-structured questionnaires to 8 village elders, 4 Members of County Assembly, one (1) imam, 3 civil organizations personnel,
\end{abstract}

\subsection{INTRODUCTION}

Like any sub-region in the world, household economic activities in Wajir East sub-County support and sustain families as well as contributing to the economic growth of Wajir County and the nation of Kenya (Amodio \& Di Maio, 2017). Unfortunately, chronic conflicts that are as old as mankind history in the North-Eastern region of Kenya, always disrupt, slow down, reverse and/or destroy hard-won household income activities in this sub-county.

Largely, these conflicts, common in North-Eastern part of Kenya are traced to long term marginalization in sharing of national resources resulting into inadequate healthcare facilities, education, infrastructure and water and sanitation among others (Ghorpade, 2017). Coupled with the hostile climate that limits drivers of social and economic transformation, marginalization has made rampant poverty, low educational achievement and low participation in national leadership, have become part and parcel of this region (Kenya Inter Agency Rapid Assessment- KIARA, 2018).

To that end, livestock is only major suitable economic activity in the sub-county like any other of North-Eastern. However, limited pasture and water due to bad weather conditions breeds competition for these key resources leading to persistent interclan conflicts. For instance, report, between 2014 to 2017 violent conflicts left 500 people killed, 800 injured, and displacement of 4,560 households.
250 police officers and 42 civilians (residents). Both descriptive and inferential findings prompted insights into conflict resolution approaches correlation with household economic development. The findings evolved recommendations to inform addressing conflict in Wajir East sub-County.

were utilized to examine academic anxiety indicators derived from previous studies and their association to students' academic performance in the perspective of 357 Technical University of Kenya. The findings provide insights into increased anxiety levels correlation with student performance.

Index Terms: Household Economic development, conflict, mediation, arbitration, negotiation.

Houses, crops, food stores, shops, were torched and vandalized, crops destroyed and over 20,000 livestock were stolen or killed (KIARA, 2018).

Undoubtedly, the conflicts have and continue to disrupt household economic engagements including livestock, cropgrowing and commercial activities. Conflicts result into killing, injuring and displacement of economically able people, disrupt movement of goods and people, as well as forcing withdrawal of existing and prospective investors and donors among other disruptions in the sub-county. (KIRA, 2018; and KRCS, 2015).

While it is appreciated countless formal resolution interventions have been made, there has been little success as conflicts still linger. Although less embraced, developed and used, alternative dispute resolutions (ADR), especially mediation, arbitration and negotiation have proved viable in conflict resolution in most conflict ravaged regions in many countries worldwide (Smith \& Frankenberger, 2018). It is this school of thought that motivated the current study to test the viability of ADR by examining the effect of mediation, arbitration and negotiation on household economic development in Wajir East sub-County.

\subsection{Problem Statement}

Economic disruptions such as the killing 500, injuring 800 and displacement of 4,560 economically able people, 
killing and stealing 20,000 livestock, destroying crops, food stores, shops and other assets persist. Also, disruption of movement of goods and people, withdrawal of existing and prospective investors and donors continue despite concerted conflicts interventions (KIRA, 2018; and KRCS, 2015).

In spite of adverse economic disruptions associated with conflict, little research exists in this area as most studies in the context of developed countries. To fill this scholarly gap, the current study sought to examine the relationships between household economic activities and conflict and generate knowledge to guide stakeholders address conflict in Wajir East sub-County.

\subsection{Research Objectives.}

The following objectives guided this study:

(i) To determine the effect of mediation on household economic development in Wajir East Sub-County, Wajir County.

(ii) To analyze the effect of arbitration on household economic development in Wajir East Sub-County, Wajir County.

(iii) To establish the effect of negotiation on household economic development in Wajir East Sub-County, Wajir County.

\section{LITERATURE REVIEW}

Tafese (2016) advises mediators to avoid biased decisions for effective mediation to resolve and reach higher the number of agreements. He further roots for use expert mediation experience to facilitate to solve cases. Lederach (2017) urges mediators to advocate for peaceful agreements and employ non-binding recommendation in cases that do not reach mutual agreement. Further, Moore, (2014), argues that collaboration ties enable a community to perform better with regard to the development goals.

Tellidis and Kappler (2016), assert that arbitration's feature of relying on evidence to make verdict qualifies it a more formal conflict mechanism that yields better dispute outcomes and to ensure a solution is binding. Also, it is prudent for decisions or solutions arrived at being confidential, prevents spread of unnecessary intrusion by busy bodies, have a verdict not be appealable.
Verme and Gigliarano (2019) opine that a negotiation process should be done in a fair and objective manner and that elders ought to apply a lot of experience and knowledge in solving cases. Additionally, they suggest that explicit rules and regulations need be established to guide negotiators in conflict resolution. According to Crost, Felter and Johnston (2016), elders forming a dominant component of the customary mechanisms of conflict management and operations of elders' courts involving older men with experience in issues related to conflict management as well as having complainants given equitable chances of personal defense negotiation process, are key in effective conflict resolution, a view shared by Muigua (2016).

\section{METHODOLOGY}

A descriptive research design was adopted. The study targeted elders, members of county assembly, imams, civil organizations personnel working in the affected region, police officers and recently worst affected conflict victims from the sub-county. Through stratified random sampling, 8 village elders, 4 Members of County Assembly and one (1) imam in the sub-county at time of the study, were sampled to participate in the research. Additionally, 3 civil organizations personnel, 250 police officers and 42 were subjected to semi-structured questionnaires to collect data.
Primary as well as secondary data formed basis for the current study. Quantitative techniques assisted in analyzing quantitative data while qualitative data was analyzed by content analysis and a prose form presentation. To determine the association between conflict resolution approaches and household economic development in Wajir East Sub-County, multiple regression model was maximized. Findings were presented in tables and figures with explanations and inferences given after every table and figure.

\section{RESULTS AND DISCUSSION}

Descriptive findings on mediation established prevalence of biased decisions, non-use of experienced, use of non-binding recommendations and collaboration ties during conflict resolution process. Inferential findings post a significant and negative $(\mathrm{B}=0613, \mathrm{t}=-2.478, \mathrm{p}=0.015)$ relationship between mediation conflict resolution approach and household economic development in Wajir East SubCounty. Implicitly, a unit change in the effectiveness of mediation conflict resolution approach would result in a unit

This publication is licensed under Creative Commons Attribution CC BY. change in household economic development by a value of 0.613 in Wajir East Sub-County.

On arbitration approach, descriptive findings reported non-reliant on evidence to make verdict, non-solution binding, lack of confidential and non-appealable verdict should.

Regression statistics $(\mathrm{B}=0.823, \mathrm{t}=-1.993, \mathrm{p}=0.049)$ demonstrated a significant and negative relationship between arbitration and household economic development. As such, a unit decrease in the arbitration conflict resolution 
ISSN 2250-3153

mechanism effectiveness would result in increase in destruction of household economic development by a value of 0.823 in Wajir East Sub-County.

Concerning negotiation conflict resolution approach, descriptive findings documented unfairness and subjectivity, elders' rare use of experience, unelaborate rules and regulations, non-involvement of experienced older men and complainants never given equitable chances of personal defense existed.

On relationship between negotiation conflict resolution approach and household economic development, the regression outcome $(\mathrm{B}=0.847, \mathrm{t}=-2.076, \mathrm{p}=0.049)$ demonstrated a significant and negative relationship between negotiation and household economic development. Specifically, a unit decrease in the negotiation effectiveness would result in a unit increase in destruction of household economic development by a value of 0.847 in Wajir East Sub-County

Overall, the research revealed that conflict resolution approaches are ineffective. This failure has let to disruption and damage of household economic development such as killing, injuring and displacement of able workforce. Also, disruption and damage of livestock and crop farming through stolen/killed, crop and food stores destruction. Too, business is disrupted and trading premises are still being torched and vandalized as well as interruption of movement of goods and people engaging in trade as well as withdraw and discouragement of donors and investors.

\section{SUMMARY, CONCLUSIONS AND RECOMMENDATIONS}

To that end, the study recommended the reconfiguration of the three conflict resolution mechanisms to prevent biased decisions, use expert mediation experience, employ nonbinding recommendations and maximization of collaboration ties during conflict resolution process. Likewise, evidence to make verdict should be relied on, make the solution binding, decisions or solutions arrived at should be confidential and a verdict should be appealable. Further, negotiation process should be fair and objective, elders should apply a lot of experience and knowledge and elaborate rules and regulations should be well-defined to guide negotiators. In addition, elders should form a dominant component of conflict management, involve older men with experience and complainants should be given equitable chances of personal defense in Wajir East Sub-County. Overall, the three dispute resolution mechanisms should be rereengineered for better dispute resolution among communities in the sub-county.
Further investigations need to be carried out to examine more conflict resolution mechanisms used in the sub-county since the current study focused on only mediation, arbitration and negotiation. Equally, more emphasis on livestock as the major economic activity of the area specifically is required to be investigated as the present study gave attention to all economic engagements of the households.

In terms of methodology, other researchers are encouraged widen the target population to include ordinary community dwellers who bear the heavy burden of conflicts to provide more empirical evidence as opposed to this study that focused exclusively on village elders. Too, new studies in this area should consider utilizing more theories, increasing the sample size and application of more research designs to generate more empirical evidence.

\section{Acknowledgment}

Dr W. Kimaru, W. Serah, Lecturer, Social and Development Studies, Mt. Kenya University

\section{REFERENCES}

Amodio, F. M., \& Di Maio (2017). Making do with what you have: Conflict, input misallocation and firm performance. The Economic Journal, 68

Crost, B., Felter, J.H., \& Johnston, P.B. (2016). Conditional cash transfers, civil conflict and insurgent influence: Experimental evidence from the Philippines. Journal of Development Economics, 118, 171-18.

Ghorpade, Y. G. (2017). Extending a Lifeline or Cutting Losses? The Effects of Conflict on Household Receipts of Remittances in Pakistan World Development, 99, pp. 230-252
Kenya Inter Agency Rapid Assessment- KIRA (2018). Kenya inter agency rapid assessment Wajir East Sub-County conflict assessment report, pp.2-11.

Kenya Red Cross Society- KRCS (2015). Wajir inter clan conflict update no. 1 on 27 th July 2015 , PP.3-15.

Lederach, J. P. (2017). Sustainable reconciliation in divided societies. Washington, DC: USIP.

Muigua, K. (2016). Managing Natural Resource Conflicts in Kenya through Negotiation and Mediation. Alternative Dispute Resolution, 1. 
Smith, L.C., \& Frankenberger, T.R (2018). Does resilience capacity reduce the negative impact of shocks on household food security? Evidence from the 2014 floods in Northern Bangladesh

Tafese, T. (2016). Conflict Management through African Indigenous Institutions: A Study of the Anyuaa Community. World Journal of Social Science, 3(1), 22.
Tellidis, I., \& Kappler, S. (2016). Information and communication technologies in peacebuilding: Implications, opportunities and challenges. Cooperation and Conflict, 51(1): 75-93

Verme, P., \& Gigliarano, C. (2019). Optimal targeting under budget constraints in a humanitarian context. World Development, 119, 224233

\section{AUTHOR}

Omar, D. Khalid, Social and Development Studies, Post-graduate Student, Mt. Kenya University. Email:

omar.daud@yahoo.com. 